\title{
Effect of Reclamation on an Environment Impaired by Mining Activity: A Case Study
}

\author{
Marian Šofranko, Ol'ga Végsöová*, Tomáš Kalász, Vladimír Sulovec, \\ Ján Beca, Martin Šuver
}

Institute of Earth Resources, BERG Faculty, Technical University of Kosice, Kosice, Slovakia

Received: 30 October 2019

Accepted: 5 December 2019

\begin{abstract}
Our paper is devoted to the reclamation of the environment degraded by mining activities. Specifically, it is about an andesite quarry in Vihorlat mountain range. The results show that stabilization of slopes is important from the point of view of technical reclamation of the environment. For mining purposes, the slope angle was defined as $60^{\circ}$. During the opening, preparation and realization of the extraction, the parameters of the operation were influenced by the cohesion in the rock mass $\mathrm{c}=14.29 \mathrm{MPa}$, bulk mass $\gamma=2.646 \mathrm{~kg}, \mathrm{~m}^{-3}$ and internal friction angle $\varphi=50-75^{\circ}$. As part of the reclamation of the degraded area, it is also necessary to perform biochemical reclamation to increase the biodiversity of the area. One possibility is to build a water tank with a bottom area of $8,700 \mathrm{~m}^{2}$. The project results in the following dam parameters: $26 \mathrm{~m}$ heel thickness, $5 \mathrm{~m}$ thickness on the top, $12 \mathrm{~m}$ width, $11 \mathrm{~m}$ height, water slope angle $42^{\circ}$ and air slope angle $51^{\circ}$. The possibilities of the reclaimed environment of the Zemplínske Hámre quarry are various.
\end{abstract}

Keywords: deposit, reclamation, revitalization, environment, slope stabilization

\section{Introduction}

Environmental impacts caused by mineral mining are becoming a major problem at local, regional, and global scales. Reclamation and revitalisation of areas affected by mining activities are an integral part of mining. The function of these activities is to eliminate impacts of mineral extraction and to restore an area so that it can again fulfil its purpose, be it recreational, forestry, agricultural or water management. Nowadays, mining companies are legally forced to plan their

*e-mail: olga.vegsoova@gmail.com mining activities in a way that minimizes the impact on the environment.

The field of reclamation in the extractive industry and its solutions is now being addressed by experts and scientists all around the world. In scientific journals we encounter various designs of models and research that show us the serious impacts on the environment as well as solutions to these real situations.

The topic is discussed in the publication "Characterizing the effects of opencast coal-mining and land reclamation on soil macropore distribution characteristics using 3D CT scanning". In this study, unmined, unreclaimed and reclaimed soils from the Antaibao opencast coal mine of the loess area from China were scanned to acquire information regarding soil macropores using a high-resolution, non-destructive 
computed tomography (CT) technique [1]. The technical paper "Digital mapping and spatial characteristics analyses of heavy metal content in reclaimed soil of industrial and mining abandoned land" discusses that the reclaimed soil properties of industrial and mining wasteland have strong spatial specificity [2]. It is also worth mentioning the following work from qualified professionals, which is called "Comprehensive landscape ecology stability assessment of a coal gangue backfill reclamation area" [3].

Also interesting is the article "Comparison of nanofiltration and direct contact membrane distillation as an alternative for gold mining effluent reclamation", which focuses on mining effluents that are possible to be used again, but first, (hazardous) metals and ions such as sulphate must be removed efficiently. This study aimed to compare the technical-economic performance of nanofiltration (NF) and direct contact membrane distillation (DCMD) on gold mining effluent treatment [4]. A very important part of the mining industry is economy and the managing processes themselves [5]. Authors Gallo and Tomcikova deal with economic methods usable in industries in more detail [6].

This issue is also dealt with by Qian, Yan, Xiu and Feng, who prepared a study "The impact of mining changes on surrounding lands and ecosystem service value in the southern slope of Qilian Mountains" [7], while experts Padró, Carabassa, Balagué, Brotons, Alcañiz and Pons focused on exploring the environment after mining in their contribution, "Monitoring opencast mine restorations using unmanned aerial system (UAS) imagery" [8].

Technical papers which also deal with environmental impacts after mining activities are "Phytoremediation: Metal decontamination of soils after the sequential forestation of former opencast coal land" [9], "Hyperspectral inversion of heavy metal content in reclaimed soil from a mining wasteland based on different spectral transformation and modelling methods" [10] and "Evaluating sediment production from native and fluvial geomorphic-reclamation watersheds at La Plata Mine" [11].

Among other significant studies in the given area are "Coal mining in Australia: Understanding stakeholder knowledge of mining and mine rehabilitation" [12], "Increases in salinity following a shift in hydrologic regime in a constructed wetland watershed in a postmining oil sands landscape" [13] and "Effects of vegetation pattern and spontaneous succession on remediation of potential toxic metal-polluted soil in mine dumps" [14].

Experts Danilov, Pashkevich and Petrova prepared an interesting study called "Environmental integrated monitoring system at reclamation of large opencast coal mine", which examines the problem of environmental pollution at all stages of the existence of a large coal mining company, especially in the stage of liquidation and reclamation, after the cessation of mining operations [15].
Significant works such as "Quality quantification model of basic raw materials" [16], "A logistic approach to establishing balanced scorecard of Russian oilproducing service organizations" [17], and "The development of selected industrial indicators in Slovakia in 2006-2016" [18] analyze the position of logistics in the mining industry. An overview of global trends of environmentally oriented logistics is provided in studies such as "The simulation model of the material flow of municipal waste recovery" [19] and "Environmental assessment of waste total recycling based on principles of logistics and computer simulation design" [20]. According to the author Eben-Chaime [21] "the flow of materials is a major constituent of in-plant logistics, and similar factors govern resource requirements and material flows".

The next study, "Post-reclamation age effects on soil physical properties and microbial activity under forest and pasture ecosystems", claims that during surface mining and subsequent reclamation efforts, physical, chemical, and biological properties of soils are disturbed [22], while another technical paper, "Sodium transport and attenuation in soil cover materials for oil sands mine reclamation", says that we examined the geochemical processes controlling $\mathrm{Na}$ transport and attenuation within the peat and clay-till cover soils at Sandhill Fen in northern Alberta, Canada [23]. Authors Omari, Das and Pinno dealt with the fact that soil stockpiling is a common reclamation practice used in oil sands mining in the boreal forest region of Canada to conserve soil resources; but stockpiling may have detrimental effects on soil quality and plant growth [24].

Sobczyk and Kowalska are also looking for solutions in this well-discussed topic, which we can find in their work "The examples of post-mining land reclamation in the public opinion" [25]. A team of Lee, Ji, Yang, Kang and Kang offer their point of view in the study "Reclamation of mine-degraded agricultural soils from metal mining: Lessons from 4 years of monitoring activity in Korea" [26]. Meanwhile, the experienced authors Pospehov, Pankratova and Straupnik prepared a conference paper on the topic "Geoengineering research for the restoration of lands disturbed by mining operations" [27]. The core of the paper of Paulo deals with the diagnosis of the environment and forecasts its changes after ceasing mining activity [28]. In the contribution "Effects of land reclamation on distribution of soil properties and heavy metal concentrations, and the associated environmental pollution assessment", you learn that there a method of "space for time substitution" was used to test the effects of reclamation history on evolution processes of soil properties and heavy metal concentrations [29].

Among other important research papers also belong "Carbon balance and life cycle assessment in an oak plantation for mined area reclamation". The studied plantation is a post-mining site located in Central Italy, 
between Firenze and Arezzo as a part of an activity of land reclamation and re-establishment of native plant species focusing on ecosystem restoration of an area where lignite was extracted [30].

\section{Theoretical Base}

Technical reclamation includes works such as terrain shaping with relocation of rocks and soils. The geological characteristics of the area indicate that the quarry field consists mainly of rocky rocks, which are stable rocks. In such conditions, the presplitting method is often used to keep the rock mass as intact and compact as possible.

The deposit of the building stone of Zemplínske Hámre is of the wall type and the mined mineral is andesite. It is part of the northern part of the neovolcanic Vihorlat mountain range, whose volcanic formations in this terrain have mesozoic rocks of the cliff zone present in the subsoil, respectively paleogenic formation of outer flysch.

Stabilization of slopes is a stage that belongs to the group of technical reclamation. First, it is necessary to ensure a safe slope angle so that there is no risk of sliding. The stabilization can be carried out either by removing the overlying layers until a safe slope is achieved or by pouring the stabilizing embankment. Slope adjustments to the final state will be carried out using excavators and impactors. The southern and southeastern walls must be secured with a protective wall.

Landscaping includes works such as levelling and grading of the quarry area, especially in a mechanized way, i. e., using excavators, graders, scrapers, impactors or bulldozers. According to the plan, landscaping will be carried out mainly in the northern and eastern parts of the quarry. After filling the work platforms with soil, it is necessary to ensure their $2 \%$ slope due to rainwater drainage. Based on the values obtained from the stability calculations, it is decided whether a stabilization embankment is needed.

At present, the drainage system is designed to tilt working platforms so that rainwater and water from the spring flow gravitationally into the nearby stream using the gutters dug at access roads. The built-up drains meet the conditions for further use after land reclamation. However, it is planned to build a small water tank that will serve as a new water surface.

The purpose of the revitalization work is to create a suitable place from the reclaimed space that fits into the surrounding ecosystem, to achieve ecological balance and to increase the biodiversity of the area. This work represents the last steps before handing the land over for practical use.

A very important stage of technical reclamation is the stabilization of slopes. First, it is necessary to ensure a safe slope angle. This is to avoid the risk of sliding. The angle of the final slopes must be determined in

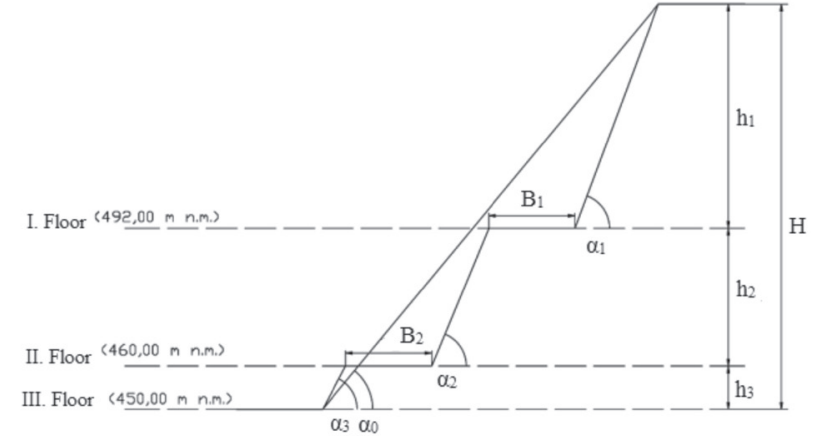

Fig. 1. Quarry geometry.

advance in the plan for the opening, preparation and extraction of the bearing (Fig. 1).

Inclination angle of mining cuts:

$$
\begin{gathered}
\alpha_{1}=\alpha_{2}=78^{\circ} \\
\alpha_{3}=70^{\circ}
\end{gathered}
$$

Width of working platforms:

$$
\mathrm{B}_{1}=\mathrm{B}_{2}=20 \mathrm{~m}
$$

Quarry wall height above the working platform:

I. floor (dimension $492.00 \mathrm{~m}$ )............................

II. floor (dimension $460.00 \mathrm{~m}$ ) ............................

III. floor (dimension $450.00 \mathrm{~m}$ ) ...........................

Total height. $\mathrm{H}=94 \mathrm{~m}$

General angle of the quarry slope

$$
\begin{gathered}
\operatorname{tg} \alpha_{0}=\frac{h_{1}+h_{2}+h_{3}}{h_{3} \times \operatorname{cotg} \alpha_{3}+\mathrm{B}_{2}+h_{2} \times \operatorname{cotg} \alpha_{2}+\mathrm{B}_{1}+h_{1} \times \operatorname{cotg} \alpha_{1}} \\
\operatorname{tg} \alpha_{0}=\frac{52+32+10}{10 \times \operatorname{cotg} 70^{\circ}+20+32 \times \operatorname{cotg} 78^{\circ}+20+52 \times \operatorname{cotg} 78^{\circ}} \\
\operatorname{tg} \alpha_{0}=56^{\circ} 37^{\prime}
\end{gathered}
$$

\section{Ecosystem Stabilization of the Surveyed Area, Case Study}

At the Zemplínske Hámre deposit, $632,000 \mathrm{~m}^{3}$ of geological reserves of building stone were calculated. Depending on the usability conditions, stocks were in full balance and according to accessibility and binding, there were $421,000 \mathrm{~m}^{3}$ of reserves available and $211,000 \mathrm{~m}^{3}$ of reserves were bound in the closing walls.

Disposal and provision of quarry operations consists of several steps to achieve the desired environmental condition. The individual work activities are designed to be carried out in stages and are listed according to their order in time.

For a better understanding of Fig. 2, the quarry field is divided into four parts, depending on the type of reclamation needed. 


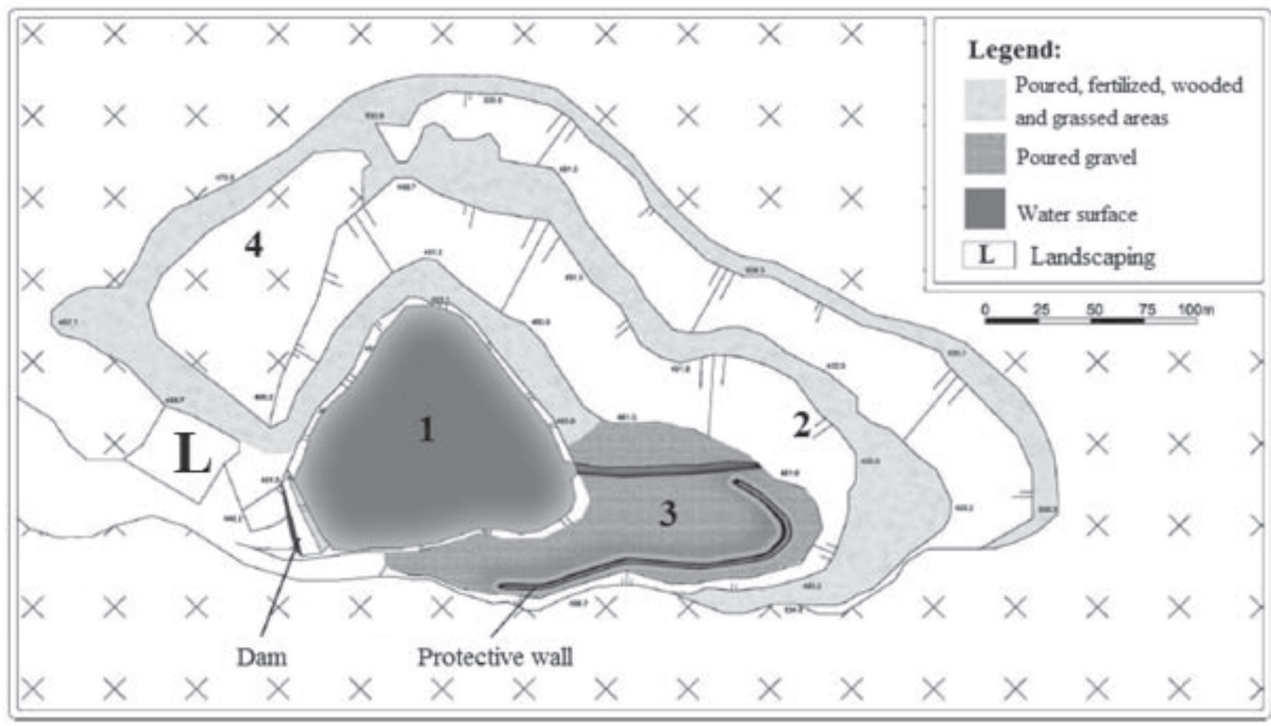

Fig. 2. Quarry field showing individual areas 1 to 4 .

To increase the biodiversity of the area, a suitable biological reclamation is proposed for separate areas:

1) A small water tank needs to be built in this area of the quarry field. From the point of view of biotechnological reclamation, there is no need to propose any activities.

2) In this part of the quarry there are $32 \mathrm{~m}$ high, weathered rocky walls with $78-80^{\circ}$ slope, which must be preserved in the most original condition and therefore are not subject to biotechnical reclamation.

3) This area needs to be technically reclaimed by levelling and grading. Biotechnical reclamation is not necessary as the ground is planned to be formed of gravel and larger pieces of rock in order to maintain the original condition.

4) This area of the quarry represents the main part in terms of biotechnical reclamation. According to measurements, this area occupies $21,000 \mathrm{~m}^{2}$. After ensuring soil stability against landslides and erosion and after landscaping, a three-year biotechnical land reclamation will be carried out.

To stabilize the slopes, it was specified in the plan for the opening, preparation and extraction of the bearing that the angle of the final slopes on the individual levels would be adjusted to $60^{\circ}$. This value shall be checked for stability whether it reflects this proposal.

According to the proposal, the south and southeast walls of the II. floor are not subject to stabilization, because they are high rocky walls, which have an interesting structure and provide a nice view of the geological structure of the area. Therefore, of the total length of II. floor - $523 \mathrm{~m}$, in terms of reclamation will be addressed only $213 \mathrm{~m}$ between northeast and east.

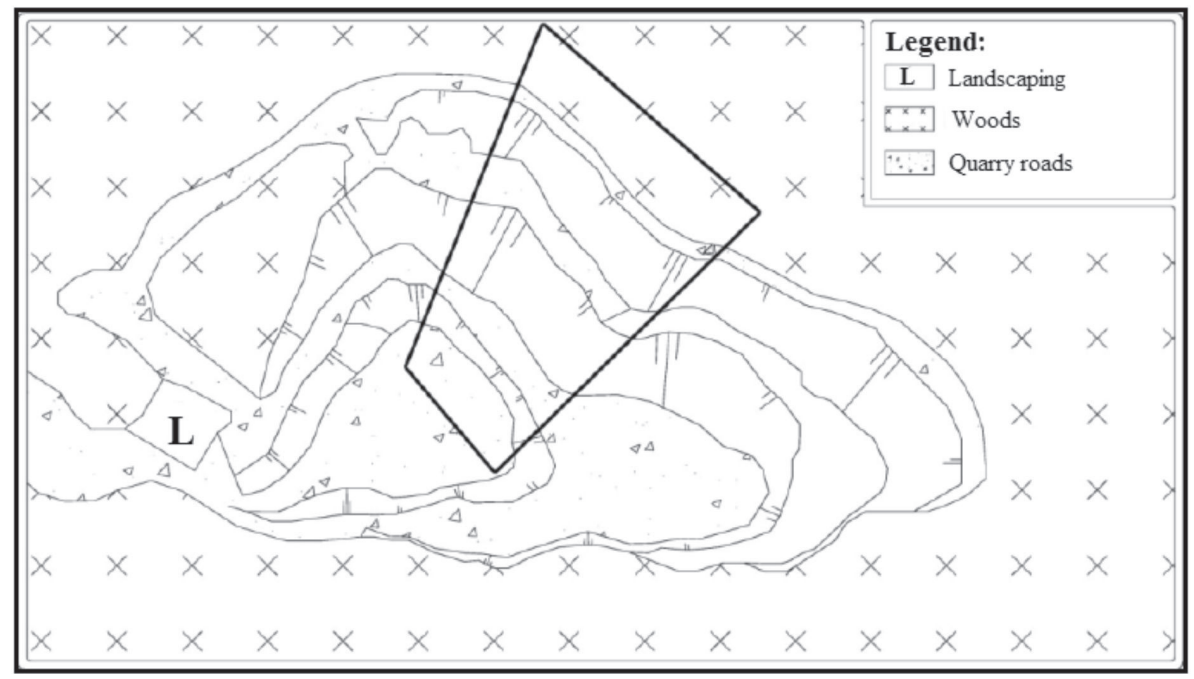

Fig. 3. Map of the quarry showing the questioned eastern area. 


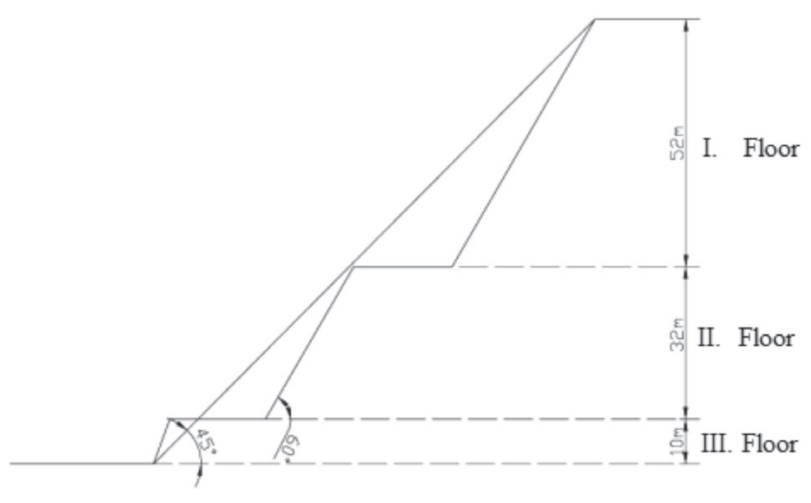

Fig. 4. Slope inclination of individual floors - eastern walls.

The following values have been identified in the opening, preparation and extraction plan:

Cohesion (for rocky rocks) ..................... c $=14.29 \mathrm{MPa}$

Bulk mass ......................................... $\gamma=2646 \mathrm{~kg} . \mathrm{m}^{-3}$

Internal friction angle (for rocky rocks) ...... $\varphi=50^{\circ}-75^{\circ}$ $\rightarrow$ chosen: 65

These values will later serve for individual calculations and modelling for the whole rock mass.

The eastern quarry wall is described in more detail in this publication, as it is the largest area in the quarry to be secured against the landslide (Fig. 3). The length of this wall section is approximately $100 \mathrm{~m}$. With the help of AutoCAD software we depicted a situation of the slopes of floors I and II on the eastern quarry wall after their treatment to a slope of $60^{\circ}$, which represents the final inclination of the slopes in Fig. 4.

The height of the first floor, $52 \mathrm{~m}$, must be understood as the highest point on the first floor, which is located at $52 \mathrm{~m}$ height, and will occupy $15-20 \mathrm{~m}$ of the total length of the floor. This section is located on the southeast side of the quarry. The questioned area is characterized by the fact that the height is mostly between $45-52 \mathrm{~m}$.

Fig. 4 shows that after adjusting all the slopes a smaller general slope angle of $45^{\circ}$ is achieved. For local rocks it was determined that the internal friction angle is between $50-75^{\circ}$. According to the plan for the opening, preparation and extraction of the bearing, the value of the internal friction angle is $65^{\circ}$ for the whole rock mass, which is significantly lower than our general slope angle after adjustment, i. e., the quarry walls will be suitably secured against sliding. This will also be verified using the model.

Using the ITASCA FLAC3D software at 3.00, a mathematical model was created about the situation of the eastern quarry walls after their adjustment to $60^{\circ}$ inclination (Fig. 5). The aim was to verify whether the massif after adjustment is sufficiently stable against landslides, by calculating the so-called FOS values. FOS (factor of safety) is calculated from the ratio of passive and active forces acting on a slope. To assess stability according to the FOS value:

$$
\begin{gathered}
\mathrm{F}<1.50 \rightarrow \text { unstable slope } \\
\mathrm{F}>1.50 \rightarrow \text { stable slope }
\end{gathered}
$$

There are more methods to calculate FOS, such as Peterson's or Bishop's methods, which use the limit equilibrium method for calculation. FLAC3D geotechnical software uses the strength reduction method (SRM) to provide more realistic stability data.

Model parameters:

Dimensions: 242.4 x 100 x $150.8 \mathrm{~m}$

Division of zones into sub-zones: 2, 2, 2 (x, y, z)

Bulk mass: 2,646 $\mathrm{kg} \mathrm{m}^{-3}$

Model: Mohr-Coulomb

Young's modulus of elasticity (E): $50 \mathrm{GPa}$

Internal friction angle: 65

Cohesion (c): $14.29 \mathrm{MPa}$

Poisson's number: 0,2

Calculation of modules:

$$
\begin{gathered}
\text { Objemový module: } K=\frac{\mathrm{E}}{3(1-2 \mu)}=\frac{50,000,000,000}{3(1-1 \times 0.2)} \\
\text { Šmykový module: } G=\frac{\mathrm{E}}{2(1+\mu)}=\frac{50,000,000,000}{2(1+0.2)}
\end{gathered}
$$

Bulk module (K): $27.7 \mathrm{GPa}$

Shear module (G): $20.83 \mathrm{Gpa}$

Based on the calculation, the slope can be considered stable as the FOS is 2.59 , therefore it is greater than the minimum value of 1.50 . Since this model represents the largest and highest continuous part of the quarry, other quarry walls will have higher FOS values, so the surrounding walls are expected to be even more stable.

It can be seen from the model that the greatest shear deformations arise along the edges of individual floors (red areas). For this reason, planting trees in these areas in the future is recommended to increase stability.

The area of the southeastern quarry wall on the first floor was investigated with the same geological character as the previous model. This wall represents the highest point in the quarry and it is relatively under the highest pressure by the mountains. After calculating the FOS value with the software, the next steps for slope stabilization are going to be decided. A fracture wall with an FOS value of 5.53 can be considered a stable wall. No further adjustments to increase slope stability are required.

The stabilization of the northern and northeastern area is determined only to some parts of II. and III. floors and access road, which is part of the first floor. For this reason, the height of the floors and the slope of the terrain is the smallest. For these quarry walls the FOS value is lower than for the eastern part. These slopes can be considered stable. In this area of the quarry it is suitable to realize mainly landscaping. Stabilization of the slopes is not necessary. 


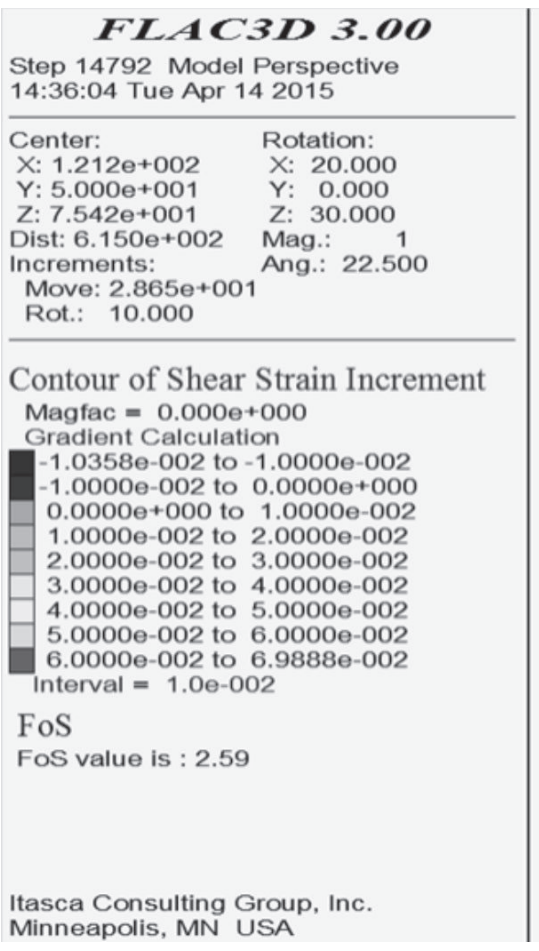

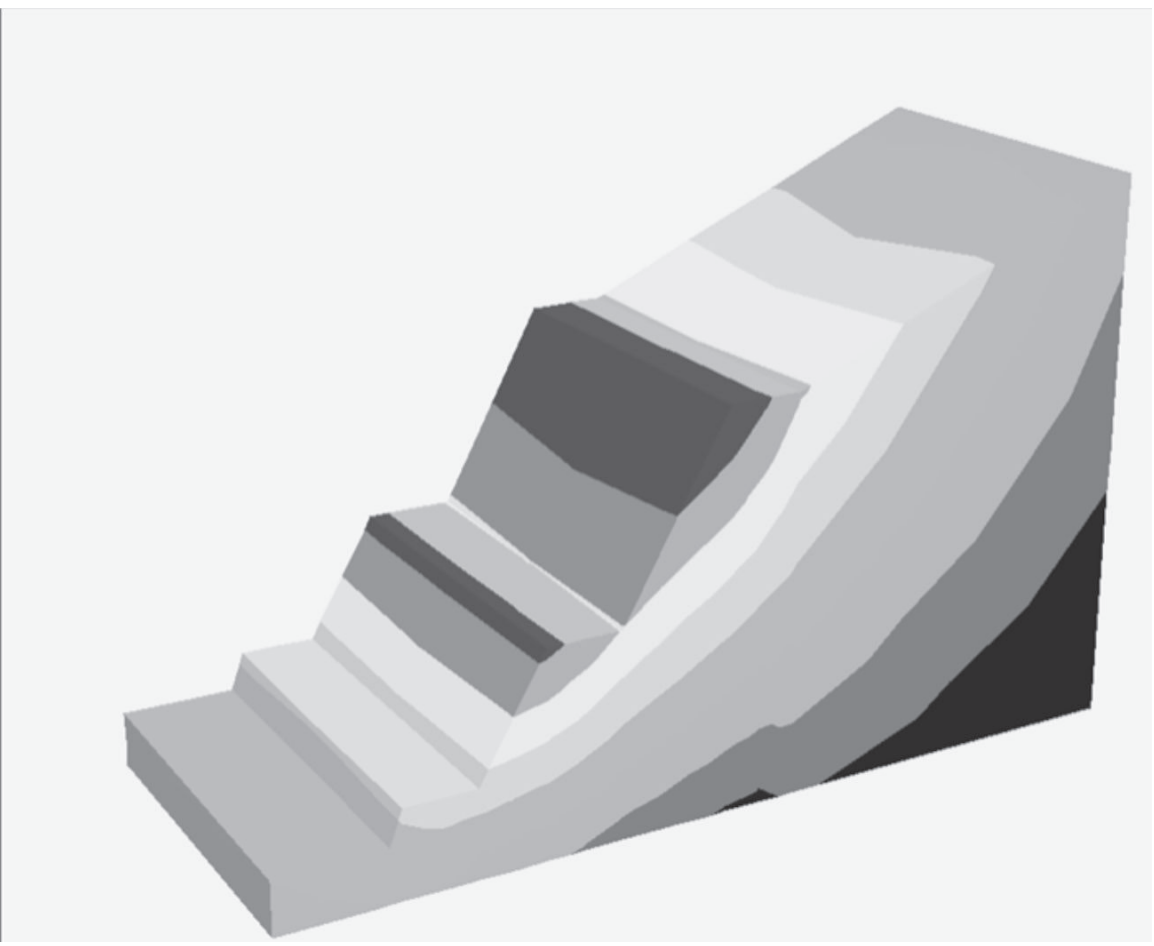

Fig. 5. Mathematical model (eastern floors).

\section{Results and Discussion}

Landscaping in area 1 concerns the design of a riverbed for the projected lake. It is necessary to consider the treatment of the bottom and the construction of the dam.

The water slope should be built so that the hydro insulation is covered with a $1.20 \mathrm{~m}$ thick layer of soil to fix the foils. The same EPDM geomembrane made of PVC will be used as the sealing element along the whole height of the water slope as for other parts of the lake bottom.

Specifically, it is about the construction of a water tank with a bottom area of $8700 \mathrm{~m}^{2}$. The construction of the dam is planned on the access road III. floor, which is $10.0 \mathrm{~m}$ wide, i.e., the dam shall be designed with a width of $10.0 \pm 1,0 \mathrm{~m}$. The tolerance of \pm 1.0 $\mathrm{m}$ is here because the access road is not bounded by perpendicular walls but by slopes with a certain inclination. The highest value (i.e., dam width $12.0 \mathrm{~m}$ ) is used for the calculation.

The tank will be filled with spring water. The spring is located on the southeast side of the II. floor. The water outflow from the spring will be solved by digging a natural gutter of $0.5 \mathrm{~m}$ width straight to the tank. As the subsoil was considered permeable, it is recommended to apply a $3 \mathrm{~cm}$ insulation layer of soil and clay with subsequent compaction. A drain with a tap (steel pipe $\varphi 35 \mathrm{~cm}$, with the possibility of closing), with a $2 \%$ inclination, is placed at the bottom of the

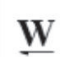

$470 \mathrm{~m} \mathrm{n} \cdot \mathrm{m}$.

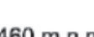

Planned dam

$460 \mathrm{~m}$ n.m.

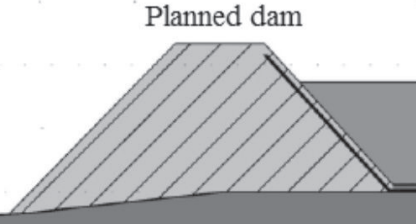

Projected lake surface $458 \mathrm{~m} \mathrm{n.m}$.

$450 \mathrm{~m}$ n.m.

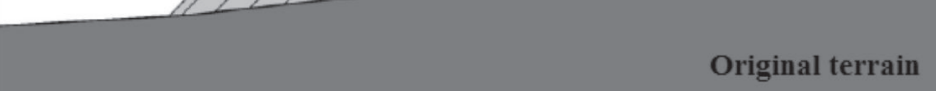

Fig.6. Projected dam and bottom hydro insulation. 


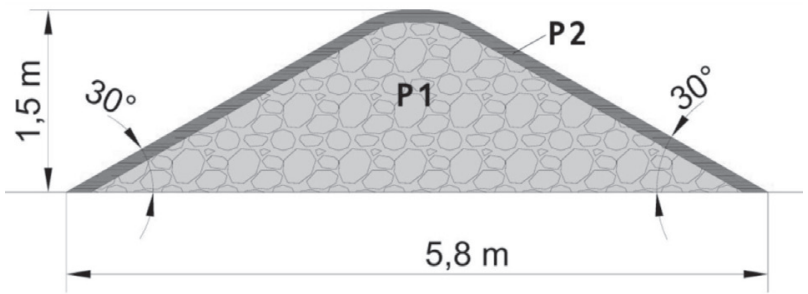

Fig. 7. Sketch of the protective wall.

dam, parallel to the terrain (Fig. 6). It is also drained by natural gutters into a nearby stream. The drainage can serve us to completely drain the lake. Keeping the water at a constant level of 8 meters ( 458 meters above sea level) is solved by a simple construction of a gutter, which is connected by drainage. The gutter must be constructed with a sieve so that no materials can enter the pipe and moderate it.

Area 2 is not subject to landscaping.

In area 3 , the terrain also needs to be levelled and graded using excavators, scrapers and impactors. According to the plan, the embankment of larger fractions of stone chips (16-32) will be applied. Such fractions will be obtained directly from quarry production, as the stone chips fraction of the stated dimensions is also produced there. The size of this area is $5,420 \mathrm{~m}^{2}$, which means that we need $800-1,100$ $\mathrm{m}^{3}$ to pour $15-20 \mathrm{~cm}$ of stone chips. After pouring the new overlay, the surface is compacted again with a soil compactor.

Since area 3 represents the area in front of the southeast walls, it has been decided, for safety reasons, to build a protective wall as shown in Fig. 7. Mound soils are not suitable for such purposes in terms of stability. Gravel or stone chips are the most suitable material for the construction of a protective wall. According to the project, in order to create a protective wall, gravel will be used, and the soil will be used to hide the mounds, which are the product of the quarry, thus reducing the total cost of reclamation.

Parameters of the protective wall:

Width: $\mathrm{w}=5.8 \mathrm{~m}$

Height: $\mathrm{h}=1.5 \mathrm{~m}$

Length: $1=120 \mathrm{~m}$

*Slope angle: $30^{\circ}$

(*The angle of the slopes was designed according to the repose angle of gravel, which is between $25-30^{\circ}$.)

Individual areas can be determined from the crosssection of the protective wall:

Gravel: $\mathrm{P} 1=4 \mathrm{~m}^{2}$

Overlaps: $\mathrm{P} 2=0.63 \mathrm{~m}^{2}$

*As we had the opportunity to use software tools, AutoCAD could easily identify the gravel surface and the overlapped area.

Material volume:

Gravel: $\mathrm{O} 1=\mathrm{P} 1 \times 1=4 \times 120=480 \mathrm{~m}^{3}$

Overlap: $\mathrm{O} 2=\mathrm{P} 2 \times 1=0.63 \times 120=75.6 \mathrm{~m}^{3}$

The overlapping volume corresponds to an ideal state where there are no pores and holes between the gravel fractions, i.e., the overlapping material does not fall between the gravel. For this reason, it is recommended to increase the designed volume of overlap by at least $30-40 \%$. The volume of overlap calculated in this way is $100-110 \mathrm{~m}^{3}$, which corresponds more to reality and can be considered a more realistic value. After filling the protective wall, approximately $7,600 \mathrm{~m}^{3}$ will remain on the mounds.

Landscaping of area 4 is work such as pouring soil, levelling and grading work platforms and the whole terrain. The working areas for soil pouring are shown in Fig. 8. This part of the quarry field, apart from the andesite streams, consists of flysch rocks as well as coarse-grained and fine-grained pyroclastic. The overlay layer with a thickness of 25-30 cm consists mainly of compacted gravel, sand, clay and soils.

As the geological structure of the area permits, the levelling and grading of the terrain and possible slope

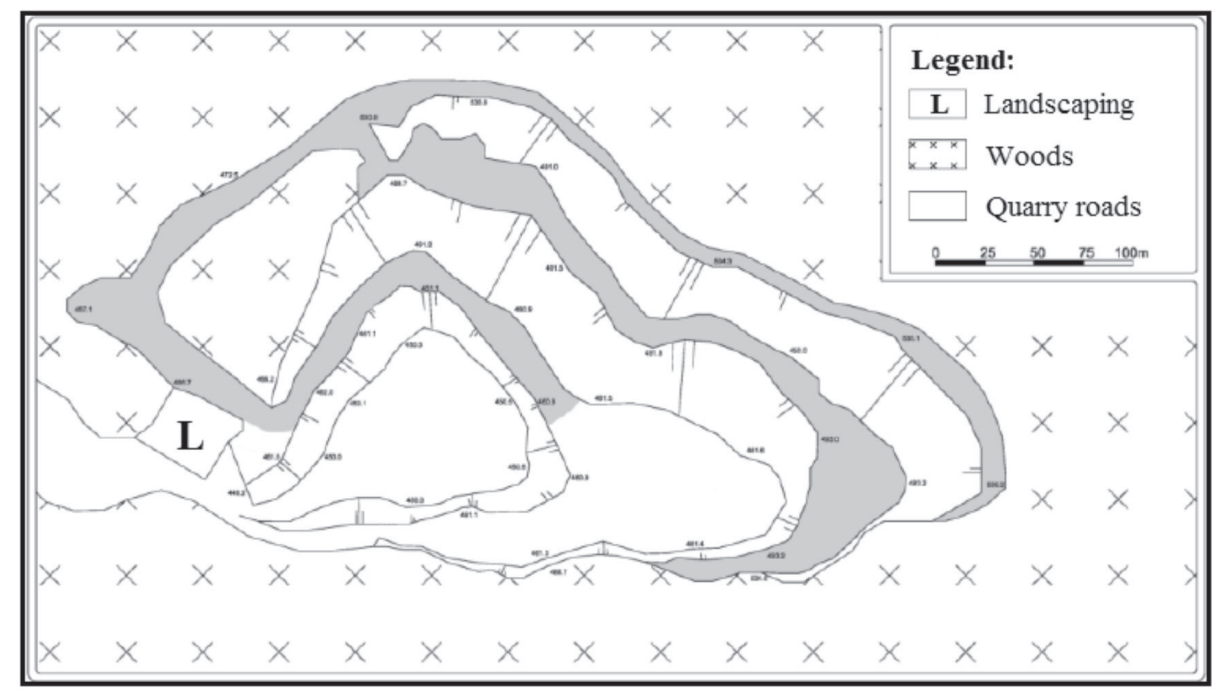

Fig. 8. Working areas intended for soil pouring. 
modification will be carried out using excavators and impactors. The embankment of a new soil layer on individual work platforms will be applied. A mixture of soils from mounds will be used as the filling material. The mound consists mainly of soils, clays and smaller aggregate fractions, which together represent about $9,500 \mathrm{~m}^{3}$ of material. The total area of the working platforms is $8,835 \mathrm{~m}^{2}$, from which we can see that $1,767 \mathrm{~m}^{3}$ of material is needed to fill the $20 \mathrm{~cm}$ layer. After pouring, it is necessary to consolidate this layer with soil compactors and then make a slope to ensure a $2 \%$ slope of the poured areas from the north due to the need for drainage. After pouring the soil, $7,737 \mathrm{~m}^{3}$ of material remains on the mounds.

\section{Conclusions}

The case study is an example of how to reclaim an environment degraded by mining activities. The reclamation procedure in the case study also can be applied universally on other types of degraded environments after mining of minerals, but also on other human interventions in the environment. The results show the following facts:

- Every year, after fertilizing and tilling the land, it is necessary to carry out work such as dragging and disking to achieve a better soil structure. This procedure after 3 years creates a 15-20 cm-thick humus layer ready for further use.

- The bottom of the tank should be treated to a level that leaves a clean surface at the end, free of substances that could have a negative effect or contaminate the water, i.e., it is necessary to extract any peat and remove landfills, manure, obstacles, boulders and building material residues. The bottom surface after treatment and cleaning should not contain sharp protrusions. After disposal, the entire bottom surface should be adjusted to a $2 \%$ slope.

- After adjusting the work platforms, it was found that $7,600 \mathrm{~m}^{3}$ of soil remained on the unused mounds. These soils are suitable as a protective layer over the insulating foil. After the subsoil has been insulated, a $30 \mathrm{~cm}$ protective layer is poured onto the foil, which is then finely compacted using a soil compactor.

- To build a dam, it is necessary to provide about $2,050 \mathrm{~m}^{3}$ of soil consisting of sandy loam and gravel. In the quarry there is a landfill of clay aggregates coming from the treatment. Landfill volume is $500-700 \mathrm{~m}^{3}$. These aggregates and soils after being cleaned from organic matter will be suitable for use as a dam-building material. The remaining volume of the dam, i.e., approx. $1,500 \mathrm{~m}^{3}$, will be solved with material from mounds. As mentioned above, after pouring the protective layer on the waterproofing membrane, the soil volume that remains on the mounds will be approx. $4,600 \mathrm{~m}^{3}$. Since the mounds contain more soils and clay than aggregates, their impermeability suits the construction of the dam, but is unsatisfactory in terms of stability. If larger aggregate fractions or larger gravel volumes are added, the stability properties of the material can be increased.

Outstanding issues include:

- What about land contaminated by oil products from mining machinery?

- What about the unnatural appearance of the environment?

- For what specific purposes to use the area in question after reclamation?

\section{Acknowledgements}

This paper is part of the projects "Research and development of new smart solutions based on principles of the industry 4.0, logistics, 3D modelling and simulation for production streamline in the mining and building industry", VEGA 1/0317/19.

\section{Conflict of Interest}

The authors declare no conflict of interest.

\section{Referencess}

1. WANG J.M., QIN Q., BAI Z.K. Characterizing the effects of opencast coal-mining and land reclamation on soil macropore distribution characteristics using 3D CT scanning. Catena, 171, 212, 2018.

2. ZHANG S.W., LIU H.L., LUO M., ZHOU X., LEI M., HUANG Y.F., ZHOU Y., GE C. Digital mapping and spatial characteristics analyses of heavy metal content in reclaimed soil of industrial and mining abandoned land. Scientific reports, 8 (1), 17150, 2018.

3. XUAN L., WENKAI L., HEBING Z., HAIPENG N. Comprehensive Landscape Ecology Stability Assessment of a Coal Gangue Backfill Reclamation Area. Polish Journal of Environmental Studies, 25 (3), 1305, 2016.

4. REIS B.G., ARAUJO A.L.B., AMARAL M.C.S., FERRAZ H.C. Comparison of Nanofiltration and Direct Contact Membrane Distillation as an alternative for gold mining effluent reclamation. Chemical engineering and processing-process intensification, 133, 24, 2018.

5. GALLO P., TAUSOVA M., GONOS J. Leadership style model based on managerial grid, Actual Problems of Economics. 178 (4), 246, 2016.

6. GALLO P., TOMCIKOVA L. The Analytical View of the Methods of Strategy Creation and Involvement of Managers of Individual Control Levels in the Production of Strategies in Strategic Management in Manufacturing Companies in the Conditions of the Slovak Republic. Quality - Access to Success, 20 (170), 3, 2019.

7. QIAN D.W., YAN C.Z., XIU L.N., FENG K. The impact of mining changes on surrounding lands and ecosystem service value in the Southern Slope of Qilian Mountains. Ecological complexity, 36, 138, 2018.

8. PADRÓ J.-C., CARABASSA V., BALAGUÉ J., BROTONS L., ALCAÑIZ J.M., PONS X. Monitoring 
opencast mine restorations using Unmanned Aerial System (UAS) imagery. Science of the Total Environment, 657, 1602, 2019.

9. DESAI M., HAIGH M. WALKINGTON H. Phytoremediation: Metal decontamination of soils after the sequential forestation of former opencast coal land. Science of the Total Environment, 656, 670, 2019.

10. ZHANG S., SHEN Q., NIE C., HUANG Y., WANG J., HU Q., DING X., ZHOU Y., CHEN Y. Hyperspectral inversion of heavy metal content in reclaimed soil from a mining wasteland based on different spectral transformation and modelling methods. Spectrochemica Acta - Part A: Molecular and Biomolecular Spectroscopy, 211, 393, 2019.

11. BUGOSH N., EPP E. Evaluating sediment production from native and fluvial geomorphic-reclamation watersheds at La Plata Mine. Catena, 174, 383, 2019.

12. SVOBODOVA K., YELLISHETTY M., VOJAR J. Coal mining in Australia: Understanding stakeholder knowledge of mining and mine rehabilitation. Energy Policy, 126, 421, 2019.

13. BIAGI K.M., OSWALD C.J., NICHOLLS E.M., CAREY S.K. Increases in salinity following a shift in hydrologic regime in a constructed wetland watershed in a post-mining oil sands landscape. Science of the Total Environmet, 653, 1445, 2019.

14. 1CHEN F., YANG Y., MI J., LIU R., HOU H., ZHANG S. Effects of vegetation pattern and spontaneous succession on remediation of potential toxic metal-polluted soil in mine dumps. Sustainability, 11 (2), 397, 2019.

15. DANILOV A.S., PASHKEVICH M.A., PETROVA T.A. Environmental integrated monitoring system at reclamation of large open-cast coal mine. InnovationBased Development of the Mineral Resources Sector: Challenges and Prospects - 11th conference of the RussianGerman Raw Materials, 20182019, 189, 2018.

16. VILAMOVA S., BESTA P., KOZEL R., JANOVSKA K., PIECHA M., LEVIT A., STRAKA M., SANDA M. Quality quantification model of basic raw materials. Metalurgija, 55 (3), 375, 2016.

17. PERMINOVA O.M., LOBANOVA G.A. A logistic approach to establishing balanced scorecard of russian oilproducing service organizations. Acta logistica, 5 (1), 1, 2018.

18. KMECOVÁ M.V., DOMARACKÁ L., TAUŠOVÁ, M. The development of selected industrial indicators in slovakia in 2006-2016. Acta logistica, 4 (4), 15-21, 2017.

19. STRAKA M., MALINDZAKOVA M., ROSOVA A., TREBUNA P. The simulation model of the material flow of municipal waste recovery. Przemysl chemiczny, 95 (4), 773, 2016.
20. STRAKA M., KHOURI S., PASKA M., BUSA M., PUSKAS D. Environmental Assessment of Waste Total Recycling Based on Principles of Logistics and Computer Simulation Design. Polish journal of environmental studies, 28 (3), 1367, 2019.

21. EBEN-CHAIME M. The overlooked dependencies of material flows on quality and quality assurance. Acta logistica, 6 (3), 85, 2019.

22. ADELI A., BROOKS J.P., READ J.J., MCGREW R., JENKINS J.N. Post-reclamation Age Effects on Soil Physical Properties and Microbial Activity Under Forest and Pasture Ecosystems. Communications in soil science and plant analysis, 50 (1), 20, 2019.

23. VESSEY COLTON J., LINDSAY MATTHEW B.J., BARBOUR S.L. Sodium transport and attenuation in soil cover materials for oil sands mine reclamation. Applied geochemistry, 100, 42, 2019.

24. OMARI K., DAS G.,S., PINNO B.D. Growth Response of Aspen and Alder to Fresh and Stockpiled Reclamation Soils. Forests, 9 (12), 731, 2018.

25. SOBCZYK W., KOWALSKA A. The Examples of Post-Mining Land Reclamation in the Public Opinion. Inzynieria mineralna - journal of the polish mineral engineering society, 2017 (1), 137, 2017.

26. LEE S.H., JI W., YANG H.J., KANG S.Y., KANG D.M. Reclamation of mine-degraded agricultural soils from metal mining: lessons from 4 years of monitoring activity in Korea. Environmental earth sciences, 76 (20), 720, 2017.

27. POSPEHOV G., PANKRATOVA K., STRAUPNIK I. Geoengineering researches for the restoration of the lands disturbed by mining operations. Engineering and Mining Geophysics 2018 - 14th Conference and Exhibition, 137600, 2018.

28. PAULO A. Environmental constraints in turning brownfields into vital community assets in the Olkusz $\mathrm{Zn}-\mathrm{Pb}$ ore district. Przeglad Geologiczny, 49 (8), 728, 2001.

29. XIAOLU Y., YUANMAN H., YU CH., YUEHUI L., MIAO L., JINGQIU Z., DANHUA Z., WEN, W. Effects of Land Reclamation on Distribution of Soil Properties and Heavy Metal Concentrations, and the Associated Environmental Pollution Assessment. Polish Journal of Environmental Studies, 26 (4), 1809, 2017.

30. BRUNORI A.M.E., SDRINGOLA P., DINI F., ILARIONI, L., NASINI L., REGNI L., PROIETTI P., PROIETTI S., VITONE A., PELLERI F. Carbon balance and Life Cycle Assessment in an oak plantation for mined area reclamation. Journal of cleaner production, 144, 69, 2017. 
